\title{
ANALYSIS OF JOB TRAINING, WORK MOTIVATION AND ORGANIZATIONAL CULTURE ON EMPLOYEE PERFORMANCE AT CLASS II A CORPORATE INSTITUTIONS, BATAM CITY
}

\author{
Riky Ismoyo $^{1}$, Indrayani ${ }^{2}$, Muamar khadafi ${ }^{3}$ \\ ${ }^{1,2}$ Faculty of Economics, Department of Management, University of Batam \\ ${ }^{3}$ Fakultas Ekonomi dan Bisnis Universitas Malikussaleh
}

\begin{abstract}
Performance of employees is important thing _ in something organization / agency. The capabilities possessed by the source power man naturally no free from a number of factor important pusher. Purpose study this is for knowing influence training work, motivation work and culture organization to performance employee at the Class II A Penitentiary of Batam City . Analysis used_that is analysis associative, trait study this is quantitative, analysis multiple linear regression and analysis coefficient determination with use IBM SPSS 22 program assistance. Population in study this is whole employee institution correctional class II A Batam City, while the sample is with use formula slovin so obtained 95 respondents . Results obtained from study this showing that : 1) Training Work take effect significant by Partial on Employee Performance in Class II A Penitentiary in Batam City, 2 ) Motivation Work take effect significant by Partial on Employee Performance in Class II A Correctional Institutions in Batam City, 3) Culture Organization take effect significant by Partial on Employee Performance in Class II A Correctional Institutions in Batam City, 4) Training Work, Motivation Work and Culture Organization take effect significant by simultaneous on Employee Performance in Class II A Penitentiary in Batam City. Adjusted R square value 0, 699 could called coefficient determination, thing this means 0, 699 (69, 9 \%) Employee Performance could obtained and explained by Training Work, Motivation Work and Culture Organization whereas the rest by $31.1 \%$ explained by variable outside the model that is not researched.
\end{abstract}

Keywords : Job Training, Work Motivation, Organizational Culture, Employee Performance

\section{INTRODUCTION}

Source Power Humans in the era of the covid-19 pandemic when this is very caring behavior ideal job for every company the place where he work, thing this naturally oblige source power man for could more interactive and have competence as well as ability more in operate activity management in the company 's internal environment. Performance of employees will considered as bone back for organization. The capabilities possessed by the source power man naturally no free from a number of factor important pusher of them is training (training) as well as motivation coming work _ from all side such as internal company and internal environment. With productive his a employee will capable give Mark positive for company as achievement of work targets, circumstances environment conducive employees, work program walk in accordance as expected and so on . A boost in energy work for could work optimally fit _ with the target expected by the company Becomes key most important in the reach the achievements expected by a company company, however thus neither does the company can ignore welfare of workers work To use as consistency in the maintain optimal performance, so that needed a the motivation that precedes somebody for enter a organization with method give what be _ desires and rights power work . Motivation from in self employee could originated from needs of money, rewards, power,

International Journal of Social Science, Educational, Economics, Agriculture Research, and Technology (IJSET) 
and recognition . Motivation from outside could originated from family, friends work nor top . Culture organization is a system belief and attitude shared development and embraced by a group of people. System belief and attitude together something organization this will differentiate it to group or organization other. Because of that, everyone member should know culture organization as method for understand, think and feel ongoing problems _ faced. So, culture organization is a normal and a value that will be shape behavior member organization that . Existence culture organization it also acts as code ethics for its members when behave outside _ environment the organization .

\section{THEORETICAL BASIS}

\section{Employee Performance (Y)}

Performance is results work that has been achieved somebody from Act in demand work in doing activity work (Sutrisno, 2017). Performance is results work by the quality and quantity achieved by a person employee in doing his job in accordance with not quite enough the answer given to him (Mangkunegara, 2017). One's performance influenced by level education employee, initiative, experience work and motivation. Work result somebody will give bait come back for for that person alone for always active do cooperation by good. Employee performance is behavior real shown _ every employee as achievement work generated _ in accordance with the role in company

\section{Training Work (X1)}

Training is competence from education learning process where the goal the that is help reach purpose organization and improve Skills by soft skills nor applicable hard skills in relative time _ short, with more method _ prioritize practice than theory . _ Mangkunegara (2017) that training and development is something that refers to related things _ with efforts planning to be implemented for reach mastery skills, knowledge, and attitudes employee or member organization

\section{Motivation Work (X2)}

according to Siagian (2016), argues that motivation work is state psychology that encourages, activates or move that directs and distributes behavior, attitudes and actions somebody for reach goal . According to Wibowo (2014), motivation work is desire for act . Everyone can _ motivated by some different strengths .

\section{Culture Organization (X3)}

Culture organization is something framework work that becomes guidelines level in demand everyday and make _ _ decision for employees and direct action they for reach purpose organization ( Rivai , 2018). Another opinion explains that culture organization is something form assumptions held, accepted _ by implicitly by the group and determine how group the feel, think and react to diverse environment _ variety ( Kreitner \& Kinicki, 2014).

\section{CONCEPTUAL FRAMEWORK}

\section{Influence Training Work Against Employee Performance}

According to Widodo (2015), training is series activity individual in Upgrade expertise and knowledge by systematic so that capable own professional performance in their field . Training is a learning process that allows employee doing current job _ in accordance with standard . according 


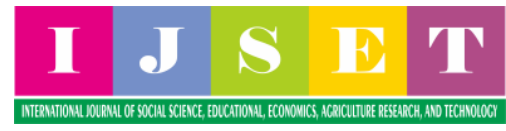

to Dessler (2015) Training is a teaching process employee new or existing _ now , skill the basis they need for operate profession them .

\section{Influence Motivation Work Against Employee Performance}

According to Robbins \& Judge (2013) motivation is a process carried out individual who strives reach goals, includes three element important that is intensity, direction, and persistence . according to Hasibuan (2016) motivation work is something stimulant desire and power mover will work somebody because every motivation have purpose certain who want achieved . Motivation that alone is the most decisive factor for a employee in work. Although ability from employee maximum accompanied with adequate facilities, however _ if no there is motivation for push employee for work in accordance purpose so profession the no will walk in accordance with purpose

\section{Influence Culture Organization Against Employee Performance}

For reach purpose the finally culture organization own strength for influence life organization and productivity work . Culture organization no will Becomes effective without existence good relationship _ between employees . For build culture organization, all perpetrator organization should be own feeling need and implement profession with sincere heart . _ Culture organization is values, principles, traditions, and ways work that is adopted shared by members organization and influence method they act (Robbins \& Coulter, 2017). Culture is one _ tools used by leaders _ for channel meaning and purpose to whole employees .

\section{IMPLEMENTATION METHOD}

Population is a generalization area consisting of on objects and subjects that have quality and characteristics specified by the researcher _ for studied then drawn conclusion, Sugiyono (2017). Population in study this is whole Batam Class II A Penitentiary employees as many as 125 employees .

Sample is part from the number and characteristics possessed by the population, Sugiyono ( 2017). For got illustrative sample _ population, then study this use formula slovin, so that total sample taken _ after calculated in study this is 95 respondents . Questionnaire given employee Class II A Penitentiary in Batam City.

\section{RESULTS AND DISCUSSION}

Validity and Reliability Test Results Variable Training Work (X1)

Table 1

Item-Total Statistics

\begin{tabular}{|l|ll|l|l|l|}
\hline & $\begin{array}{l}\text { Scale Mean if Item } \\
\text { Deleted }\end{array}$ & $\begin{array}{l}\text { Scale Variance if Item } \\
\text { Deleted }\end{array}$ & $\begin{array}{l}\text { Corrected } \\
\text { Correlation }\end{array}$ & Item-Total & $\begin{array}{l}\text { Cronbach's Alpha if Item } \\
\text { Deleted }\end{array}$ \\
\hline P1.1 & 30.46 & 24,847 & .492 & .854 \\
P1.2 & 30.42 & 24,757 & .477 & .856 \\
P1.3 & 30.17 & 24,822 & .521 & .851 \\
P1.4 & 30.41 & 22.628 & .751 & .828 \\
P1.5 & 30.57 & 22,397 & .696 & .833 \\
P1.6 & 30.51 & 25,380 & .483 & .854 \\
P1.7 & 30.39 & 25,708 & .451 & .857 \\
P1.8 & 30.36 & 22,594 & .753 & .828 \\
\hline
\end{tabular}

International Journal of Social Science, Educational, Economics, Agriculture Research, and Technology (IJSET) 
Volume 1 Issue 2 (2022)

ANALYSIS OF JOB TRAINING, WORK MOTIVATION AND ORGANIZATIONAL CULTURE ON EMPLOYEE PERFORMANCE AT CLASS II A CORPORATE INSTITUTIONS, BATAM CITY DOI: https://doi.org/10.54443/ijset.v1i2.12

\section{Item-Total Statistics}

\begin{tabular}{|l|l|l|l|l|l|}
\hline & $\begin{array}{l}\text { Scale Mean if Item } \\
\text { Deleted }\end{array}$ & $\begin{array}{l}\text { Scale Variance if Item } \\
\text { Deleted }\end{array}$ & $\begin{array}{l}\text { Corrected } \\
\text { Correlation }\end{array}$ & Item-Total & $\begin{array}{l}\text { Cronbach's Alpha if Item } \\
\text { Deleted }\end{array}$ \\
\hline P1.1 & 30.46 & 24,847 & .492 & .854 \\
P1.2 & 30.42 & 24,757 & .477 & .856 \\
P1.3 & 30.17 & 24,822 & .521 & .851 \\
P1.4 & 30.41 & 22.628 & .751 & .828 \\
P1.5 & 30.57 & 22,397 & .696 & .833 \\
P1.6 & 30.51 & 25,380 & .483 & .854 \\
P1.7 & 30.39 & 25,708 & .451 & .857 \\
P1.8 & 30.36 & 22,594 & .753 & .828 \\
P1.9 & 30.57 & 22,929 & .641 & .839 \\
\hline
\end{tabular}

Source : Data processed by SPSS (2022)

Based on The table above, the results from the validity test as many as 9 items statement on variable training work is said to be valid ( legitimate ) because Mark corrected item total correlation $>0.30$.

Table 2

Reliability Statistics

\begin{tabular}{|c|c|}
\hline $\begin{array}{l}\text { Cronbach's } \\
\text { Alpha }\end{array}$ & N of Items \\
\hline .860 & 9 \\
\hline
\end{tabular}

Source : Data processed by SPSS (2022)

Based on The table above, the results from reliability test as many as 9 items statement on variable training work is said to be reliable / reliable because Mark cronbach's alpha $0.860>0.60$.

\section{Validity and Reliability Test Results Variable Motivation Work (X2)}

Table 3

Item-Total Statistics

\begin{tabular}{|l|r|r|r|r|}
\hline & \multicolumn{2}{|l|}{$\begin{array}{l}\text { Corrected Item- } \\
\text { Scale } \\
\text { Item Deleted }\end{array}$} & $\begin{array}{l}\text { Cronbach's } \\
\text { Alpha if Item } \\
\text { Deleted }\end{array}$ \\
\hline P2.1 & 26.54 & 20,719 & .655 & .818 \\
P2.2 & 26.56 & 20,037 & .721 & .809 \\
P2.3 & 26.62 & 20,791 & .602 & .824 \\
P2.4 & 26.37 & 20,427 & .693 & .813 \\
P2.5 & 26.42 & 20,544 & .702 & .812 \\
P2.6 & 26.53 & 21,677 & .473 & .841 \\
P2.7 & 26.29 & 22.104 & .464 & .841 \\
P2.8 & 26.44 & 22,994 & .359 & .853 \\
\hline
\end{tabular}

Source : Data processed by SPSS (2022)

Based on The table above, the results from the validity test as many as 8 items statement on variable motivation work is said to be valid ( legitimate ) because Mark corrected item total correlation $>0.30$. 


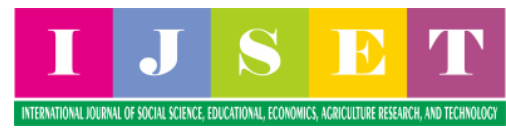

Table 4

Reliability Statistics

\begin{tabular}{|r|r|}
\hline $\begin{array}{l}\text { Cronbach's } \\
\text { Alpha }\end{array}$ & N of Items \\
\hline .845 & 8 \\
\hline
\end{tabular}

Source : Data processed by SPSS (2022)

Based on The table above, the results from reliability test as many as 8 items statement on variable motivation work is said to be reliable / reliable because Mark cronbach's alpha $0.845>0.60$.

\section{Validity and Reliability Test Results Variable Culture Organization (X3)}

Table 3

Item-Total Statistics

\begin{tabular}{|c|c|c|c|c|}
\hline & \begin{tabular}{|l|}
\multicolumn{2}{|c|}{ Scale } \\
Mean if Item \\
Deleted
\end{tabular} & $\begin{array}{c}\text { Scale } \\
\text { Variance if Item } \\
\text { Deleted }\end{array}$ & $\begin{array}{l}\text { Correcte } \\
\text { d Item-Total } \\
\text { Correlation }\end{array}$ & $\begin{array}{l}\text { Cronbach' } \\
\text { s Alpha if Item } \\
\text { Deleted }\end{array}$ \\
\hline P3.1 & 26.59 & 19,734 & .561 & .850 \\
\hline P3.2 & 26.61 & 18,581 & .709 & .832 \\
\hline P3.3 & 26.73 & 19,222 & .661 & .838 \\
\hline P3.4 & 26.45 & 19,953 & .554 & .850 \\
\hline P3.5 & 26.59 & 19,564 & .606 & .844 \\
\hline P3.6 & 26.61 & 19,645 & .568 & .849 \\
\hline P3.7 & 26.39 & 19.262 & .617 & .843 \\
\hline P3.8 & 26.54 & 20,060 & .586 & .847 \\
\hline
\end{tabular}

Source : Data processed by SPSS (2022)

Based on The table above, the results from the validity test as many as 8 items statement on variable culture the organization is said to be valid ( legitimate ) because Mark corrected item total correlation $>0.30$.

Table 4

Reliability Statistics

\begin{tabular}{|r|r|}
\hline $\begin{array}{c}\text { Cronbac } \\
\text { h's Alpha }\end{array}$ & $\begin{array}{r}\text { N of } \\
\text { Items }\end{array}$ \\
\hline .861 & 8 \\
\hline
\end{tabular}

Source : Data processed by SPSS (2022)

Based on The table above, the results from reliability test as many as 8 items statement on variable culture the organization is said to be reliable/ reliable because Mark cronbach's alpha $0.861>0.60$.

Validity and Reliability Test Results Employee Performance Variable (Y)

Table 5

Item-Total Statistics

\begin{tabular}{|l|c|c|c|c|}
\hline & $\begin{array}{r}\text { Scale } \\
\text { Mean if Item } \\
\text { Deleted }\end{array}$ & $\begin{array}{r}\text { Variance if Item } \\
\text { Deleted }\end{array}$ & $\begin{array}{r}\text { Correcte } \\
\mathbf{d} \text { Item-Total } \\
\text { Correlation }\end{array}$ & $\begin{array}{r}\text { Cronbach' } \\
\text { s Alpha if Item } \\
\text { Deleted }\end{array}$ \\
\hline Y.1 & 26.79 & 15,679 & .380 & .755 \\
\hline
\end{tabular}


Volume 1 Issue 2 (2022)

ANALYSIS OF JOB TRAINING, WORK MOTIVATION AND ORGANIZATIONAL CULTURE ON EMPLOYEE PERFORMANCE AT CLASS II A CORPORATE INSTITUTIONS, BATAM CITY DOI: https://doi.org/10.54443/ijset.v1i2.12

\begin{tabular}{|l|l|l|l|l|} 
Y.2 & 26.69 & 16,108 & $\mathbf{. 3 1 0}$ & .766 \\
Y.3 & 26.73 & 15,180 & $\mathbf{. 4 5 4}$ & .742 \\
Y.4 & 26.80 & 14,374 & $\mathbf{. 5 7 0}$ & .721 \\
Y.5 & 26.97 & 14,520 & $\mathbf{. 5 0 5}$ & .733 \\
Y.6 & 26.82 & 15,659 & $\mathbf{. 3 7 5}$ & .756 \\
Y.7 & 26.87 & 14,771 & $\mathbf{. 5 1 3}$ & .732 \\
Y.8 & 26.82 & 14.106 &. $\mathbf{6 0 8}$ & .714 \\
\hline
\end{tabular}

Source : Data processed by SPSS (2022)

Based on The table above, the results from the validity test as many as 8 items statement on variable performance employees are said to be valid ( legitimate ) because Mark corrected item total correlation $>0.30$.

Table 6

Reliability Statistics

\begin{tabular}{|c|c|}
\hline $\begin{array}{c}\text { Cronbac } \\
\text { h's Alpha }\end{array}$ & $\begin{array}{c}\text { N of } \\
\text { Items }\end{array}$ \\
\hline .765 & 8 \\
\hline
\end{tabular}

Source : Data processed by SPSS (2022)

Based on The table above, the results from reliability test as many as 8 items statement on variable performance employees are said to be reliable/ reliable because Mark cronbach's alpha $0.765>0.60$.

\section{Normality Test Results ( Kolmogorove -Smirnov Test)}

Table 7

One-Sample Kolmogorov-Smirnov Test

\begin{tabular}{|ll|l|}
\hline & & $\begin{array}{r}\text { Unstanda } \\
\text { rdized Residual }\end{array}$ \\
\hline Normal Parameters a ,b & mean & \multicolumn{1}{c|}{95} \\
& Std. Deviation & .0000000 \\
Most Extreme Differences & Absolute & 2.35377190 \\
& Positive & .061 \\
& negative & .061 \\
Kolmogorov-Smirnov Z & & -.052 \\
asymp . Sig. (2-tailed) & & .593 \\
\hline
\end{tabular}

a. Test distribution is Normal.

b. Calculated from data.

Based on Table 7 is known that Mark asymp . Sig. (2-tailed) $0.874>0.05$ value significance so that could concluded that the tested data is normally distributed .

\section{Multicollinearity Test Results}

\section{Table 8}

\begin{tabular}{|c|c|c|}
\hline \multirow{2}{*}{ Model } & \multicolumn{2}{|c|}{$\begin{array}{c}\text { Collinearity } \\
\text { Statistics }\end{array}$} \\
\cline { 2 - 3 } & \multicolumn{2}{|c|}{\begin{tabular}{c|} 
Tole \\
rance
\end{tabular}} \\
\hline
\end{tabular}




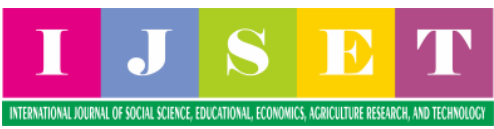

\begin{tabular}{|l|l|l|}
\hline 1 (Constant) & \\
Training Work & .588 & 1,701 \\
Motivation Work & .756 & 1.323 \\
Culture & .612 & 1,635 \\
Organization & & \\
\hline
\end{tabular}

Source : Data processed by SPSS (2022)

Based on Table 8 is known that multicollinearity test results for variable training work , motivation work and culture organization own Mark tolerance $>0.10$ and VIF $<10$ then study this declared free from problem multicollinearity

Multiple Linear Regression Results

Table 9

\begin{tabular}{|c|l|l|}
\hline \multirow{2}{*}{ Model } & \multicolumn{3}{|c|}{$\begin{array}{c}\text { Unstandardized } \\
\text { Coefficients }\end{array}$} \\
\cline { 2 - 3 } & & \multicolumn{1}{|c|}{$\begin{array}{c}\text { Std. } \\
\text { B }\end{array}$} \\
\hline (Crror \\
\hline Training Work & $\mathbf{3 . 9 1 9}$ & 1.851 \\
Motivation Work &. $\mathbf{2 2 0}$ & .059 \\
Culture &. $\mathbf{4 4 6}$ & .055 \\
Organization & & .063 \\
\hline
\end{tabular}

Source : Data processed by SPSS (2022)

a) Constant $=3,919$

From constant $=3,919$ could known that training work, motivation work and culture organization no increase or value 0 ( zero ) then performance employee of 3,919 units .

b) $1=0.220$

if any policy to training work up one unit so performance employee increase by 0.220 unit .

c) $2=0.187$

if any policy to motivation work go up one unit so performance employee up by 0.187 _ unit .

d) $3=0.446$

if any policy to culture organization go up one unit so performance employee up by 0.446 - unit .

\section{F Test Results ( Simultaneous Test )}

Table 10

ANOVA ${ }^{b}$

\begin{tabular}{|c|c|c|c|c|c|c|}
\hline & Model & $\begin{array}{l}\text { Sum of } \\
\text { Squares }\end{array}$ & $d f$ & $\begin{array}{l}\text { Mean } \\
\text { Square }\end{array}$ & $\mathbf{F}$ & Sig. \\
\hline \multirow[t]{3}{*}{1} & Regression & 1267,049 & 3 & 422.350 & 73,800 & $.000^{a}$ \\
\hline & Residual & 520.783 & 91 & 5.723 & & \\
\hline & Total & 1787,832 & 94 & & & \\
\hline
\end{tabular}


Volume 1 Issue 2 (2022)

ANALYSIS OF JOB TRAINING, WORK MOTIVATION AND ORGANIZATIONAL CULTURE ON EMPLOYEE PERFORMANCE AT CLASS II A CORPORATE INSTITUTIONS, BATAM CITY DOI: https://doi.org/10.54443/ijset.v1i2.12

a. Predictors: (Constant), Culture Organization, Motivation Work, Training Work

b. Dependent Variable: Employee Performance

Source : Data processed by SPSS (2022)

Based on Table 10 can be seen that the $\mathrm{F}$ test produces $\mathrm{F}$ count $73,800>\mathrm{F}_{\text {table }} 2,47$ (nk-1 at $\mathrm{k}=95-4-1=90$ at 4) and a significance of $0.000<0.05$, so Ha is accepted and Ho is rejected , meaning training work, motivation work and culture organization by simultaneous take effect to performance employee .

T-Test Results ( Partial Test )

Table 11

\begin{tabular}{|l|l|l|}
\hline & & \\
\hline \multicolumn{1}{|c|}{ Model } & & Sig. \\
\hline (Constant) & 2.117 & .037 \\
Training Work & 3,744 & .000 \\
Motivation Work & 3.418 & .001 \\
Culture & 7.062 & .000 \\
Organization & & \\
\hline
\end{tabular}

Source : Data processed by SPSS (2022)

Based on Table 11 can known that numbers variable free each other influence variable tied. Criteria taking decision :

Accept Ho ( reject Ha) if $\mathrm{t}_{\text {count }}<\mathrm{t}_{\text {table }}$ or Sig $\mathrm{t}>5 \%$.

Reject Ho ( accept Ha) if $\mathrm{t}_{\text {count }}>\mathrm{t}_{\text {table }}$ or $\mathrm{Sig} \mathrm{t}<5 \%$.

1) Influence Training Work To Employee Performance

$\mathrm{t}$ value training work of $3.744<1.66(\mathrm{nk}=95-4=91$ at $0.05 / 5 \%)$ and a significance of $0.000<0.05$, so $\mathrm{Ha}$ is accepted and Ho is rejected, then training work influential and significant by Partial to performance employee .

2) Influence Motivation Work To Employee Performance

$\mathrm{t}$ value motivation work of $3.418<1.66(\mathrm{nk}=95-4=91$ at $0.05 / 5 \%)$ and a significance of $0.000<0.05$, so $\mathrm{Ha}$ is accepted and Ho is rejected, then motivation work influential and significant by Partial to performance employee .

3) Influence Culture Organization To Employee Performance

$\mathrm{t}$ value culture organization of $7.062<1.66(\mathrm{nk}=95-4=91$ at $0.05 / 5 \%)$ and a significance of $0.000<0.05$, so $\mathrm{Ha}$ is accepted and $\mathrm{Ho}$ is rejected, then culture organization influential and significant by Partial to performance employee .

\section{Coefficient Test Results Determination}

Table 12

\begin{tabular}{|l|l|l|l|l|}
\hline odel & $R$ & R Square & $\begin{array}{l}\text { Adjusted } \\
\text { Square }\end{array}$ & $\begin{array}{l}\text { Std. Error of } \\
\text { the Estimate }\end{array}$ \\
\hline & $.842^{\mathrm{a}}$ & .709 & .699 & 2,392 \\
\hline
\end{tabular}

Source : Data processed by SPSS (2022)

From Table 12 it can be known acquisition Mark Adjusted $R$ square 0, 699 could called coefficient determination, thing this means 0, 699 (69, $9 \%$ ) Employee Performance could 
obtained and explained by Training Work, Motivation Work and Culture Organization whereas the rest by $31.1 \%$ explained by variable outside the model that is not researched .

\section{1) Influence Training Work Against Employee Performance}

$\mathrm{t}$ value training work of $3.744<1.66(\mathrm{nk}=95-4=91$ at $0.05 / 5 \%)$ and a significance of $0.000<0.05$, so Ha is accepted and Ho is rejected, then training work influential and significant by Partial to performance employee .

On variable Training Work (X1) result from the validity test as many as 9 items statement on variable training work is said to be valid ( legitimate ) because Mark coefficient more large > 0.30 , and reliability test results said reliable because Mark cronbach's alpha $>0.60$.

Activity training every employee should capable accept all understanding given by the speaker or source person in Upgrade insight, competence as well as ability in customized work _ with not quite enough answer work, then from that training provided _ character interaction by direct to employee through online media during the pandemic use zoom app, google meet and others

\section{2) Influence Motivation Work Against Employee Performance}

$\mathrm{t}$ value motivation work of $3.418<1.66(\mathrm{nk}=95-4=91$ at $0.05 / 5 \%)$ and a significance of $0.000<0.05$, so $\mathrm{Ha}$ is accepted and Ho is rejected, then motivation work influential and significant by Partial to performance employee .

On variable Motivation Work (X2) result from the validity test as many as 8 items statement on variable motivation work is said to be valid ( legitimate ) because Mark coefficient more large $>0.30$, and reliability test results said reliable because Mark cronbach's alpha $>0.60$.

Whole employee who runs activity work on a environment work should own ability in apply the ideal strategy to complete every work for more effective in accordance as expected _ with ability the employee will with easy complete obligation as well as not quite enough answer work provided by the company in accordance with work targets that will achieved, good work strategy will apply commitment important to yourself a employee for could give all the best

\section{3) Influence Culture Organization Against Employee Performance}

$\mathrm{t}$ value culture organization of $7.062<1.66(\mathrm{nk}=95-4=91$ at $0.05 / 5 \%)$ and a significance of $0.000<0.05$, so $\mathrm{Ha}$ is accepted and $\mathrm{Ho}$ is rejected, then culture organization influential and significant by Partial to performance employee .

On variable Culture Organization (X3) results from the validity test as many as 8 items statement on variable culture the organization is said to be valid ( legitimate ) because Mark coefficient more large $>0.30$, and reliability test results said reliable because Mark cronbach's alpha $>0.60$.

For reach purpose the finally culture organization own strength for influence life organization and productivity work . Culture organization no will Becomes effective without existence good relationship _ between employees. For build culture organization, all perpetrator organization should be own feeling need and implement profession with sincere heart .

\section{CONCLUSION}

1. Training Work influential and significant by Partial to Employee Performance in Class II A Penitentiary in Batam City .

2. Motivation Work influential and significant by Partial to Employee Performance in Class II A Penitentiary in Batam City . 
3. Culture Organization influential and significant by Partial to Employee Performance in Class II A Penitentiary in Batam City .

4. Training Work, Motivation Work and Culture Organization take effect significant by simultaneous to Employee Performance in Class II A Penitentiary in Batam City .

\section{REFERENCES}

Agoes, S. 2008. Auditing (Pemeriksaan Akuntansi) oleh Kantor Akuntan Publik.Edisi ketiga cetakan keempat.Lembaga Penerbitan Fakultas Ekonomi Universitas Jakarta.Jakarta.

Arens, A.A., J.K. Loebbecke. 2000. Auditing: An Integrated Approach. Eight Edition. New Jersey: Prentice Hall International Inc.

Atmawinata, Susilawati.2014. "Pengaruh Profesionalisme Dan Independensi Auditor Internal Terhadap Kualitas Audit: Studi Pada Inspektorat Propinsi Jawa Barat" Jurnal Etikonomi . STIE STEMBI. Vol. 13 No. 2 Oktober 2014

De Angelo, L.E. 1981. Auditor Size and Audit Quality. Journal of Accounting and Economic 3, pp: 183-199

Efendy. (2010). "Pengaruh Kompetensi, Independensi dan Motivasi auditor terhadap Kualitas Audit Inspektorat dalam Pengawasan Keuangan Daerah" (Studi Empiris pada Pemerintah Kota Gorontalo). Universitas Dipenogoro.

Ghozali, Imam (2011), Aplikasi Analisis Multivariate Dengan Program SPSS, Semarang: Badan Penerbit Universitas Diponegoro.

Ilham, R. N., Erlina, K. A. F., Silalahi, A. S., Saputra, J., \& Albra, W. (2019). Investigation of the bitcoin effects on the country revenues via virtual tax transactions for purchasing management. Int. J Sup. Chain. Mgt Vol, 8(6), 737.

Ilham, R. N., Sinaga, S., Putri, D. E., Sinta, I., \& Fuadi, F. (2021). EFEK DARI LEVERAGE DAN UKURAN PERUSAHAAN DALAM MEMENGARUHI TINGKAT PROFITABILITAS. JURNAL ILMIAH EDUNOMIKA, 5(02).

Khaddafi, M., Subrata, H., Apriyanto, E., Iqbal, M., \& Darmawan, W. (2022). PENGENALAN DASAR PENGOPERASIAN KOMPUTER PADA ANAK USIA DINI. JATIMIKA: Jurnal Kreativitas Mahasiswa Informatika, 2(3).

Natawirani, Putu dan I Gde Ary. 2017. "Pengaruh Kompleksitas Tugas, Independensi Dan Komitmen Profesional Pada Kualitas Audit". E-Jurnal Akuntansi Universitas Udayana. Vol.18.1. Januari (2017): 735-762

Rumengan Jemmy, 2013. Metodologi Penelitian. Bandung : Citapustaka Media Perintis Suardinatha, Made dan Made G Wirakusuma.2016. "Pengaruh Independensi Dan

Profesionalisme Terhadap Kualitas Audit Dengan Kepuasan Kerja Sebagai Variabel Pemoderasi”. E-Jurnal Akuntansi Universitas Udayana. Vol.17.3. Desember (2016)

Santoso, J. T., Ginantra, N. L. W. S. R., Arifin, M., Riinawati, R., Sudrajat, D., \& Rahim, R. (2021). Comparison of Classification Data Mining C4. 5 and Naïve Bayes Algorithms of EDM Dataset.

Sugiyono. 2008. Metode Penelitian Kuantitatif, Kualitatif, dan R\&D. Penerbit Alfabeta. Bandung.

Sugiyono. 2014. Metode Penelitian Kuantitatif Kualitatif dan R\&D. Bandung : CV. Alfabeta Alfabeta

Wadji, Andi. 2013. “Pengaruh Profesionalisme, Indenpendensi Auditor Dan Kompleksitas Tugas Terhadap Kualitas Audit Dengan Pendidikan Dan Pelatihan Audit Sebagai Variabel Moderasi”. Jurnal Informasi Perpajakan, Akuntansi Dan Keuangan Publik. Vol.8 No.2 Juli 2013. Hal : $87-10$ 